\title{
Vegetation of rock clefts and ledges in the Pamir Alai Mts, Tajikistan (Middle Asia)
}

\section{Research Article}

Arkadiusz Nowak ${ }^{1, *}$, Sylwia Nowak ${ }^{1}$, Marcin Nobis$^{2}$, Agnieszka Nobis $^{2}$

'Department of Biosystematics, Laboratory of Geobotany and Plant Conservation, Opole University, 45-052 Opole, Poland

2Department of Plant Taxonomy, Phytogeography and Herbarium, Institute of Botany, Jagiellonian University,

31-501 Kraków, Poland

Received 23 September 2013; Accepted 21 October 2013

Abstract: The paper presents the results of phytosociological research conducted on the vegetation of rock clefts and ledges in the Pamir-Alai Mountains (Tajikistan, Middle Asia). During the field studies, done in 2010-2012, 101 phytosociological relevés were taken. Plant species were recorded according to the Braun-Blanquet cover-abundance scale. Communities of calcareous rock clefts and ledges with small soil amounts from several ranges (Zeravshan Mts, Hissar Mts, Hazratishokh Mts, Darvaz Mts, Rushan Mts and Vanch Mts), inhabiting mainly the alpine and subnival zone, have been described. A synopsis of the rock communities of the Pamir-Alai is proposed. In the examined vegetation plots 77 vascular plant and 6 moss species were noted. The most frequent were: Achoriphragma pinnatifidum, Artemisia rutifolia, Asperula albiflora, Campanula incanescens, C. lehmanniana, Parietaria judaica, Pentanema albertoregelia, Poa relaxa and Stipa zeravshanica among vascular plants and Brachythecium albicans and Bryum caespiticum among mosses. Most of them are narrow endemics of Tajikistan or Middle Asia. The collected material presents most of the variability among the phytocoenoses of large crevices and rock ledges in limestone massifs in the alpine and subnival zones. As a result of field research and numerical analyses, 7 associations have been distinguished: Achoriphragmetum pinnatifidi, Asperulo albiflorae-Stipetum zeravshanicae, Inuletum glaucae, Paraquilegietum anemonoidis, Pentanemetum albertoregeliae, Rhinactinidietum popovii and Saussureaetum ovatae. The distinctiveness of habitat and species composition of Middle Asiatic rock communities makes it necessary to distinguish a new suballiance, Pentanemenion albertoregeliae, within the Asperulo albiflorae-Poion relaxae alliance. The main factors determining the species composition of classified associations seem to be the elevation above sea level and exposition. Alpine rock communities are one of the most unique and interesting plant formations in the moutainous areas of Pamir-Alai. Despite not being species-rich they often harbour many specialists adapted to harsh and extreme environments, especially in areas of Mediterranean-like climate.

Keywords: Asplenietea trichomanis • Alpine vegetation $\bullet$ Petrophytes $・$ Chasmophytes $・$ Syntaxonomy

(C) Versita Sp. z 0.0 .

\section{Introduction}

Tajikistan is a mountainous country located in the Middle Asia with two main ranges of Pamir Alai and TianShan within its borders. According to the literature and herbarium data ca. 4,550 vascular plant species occur in this country [1-13]. This number is still increasing due to recent floristic studies with records of plant species new to the Tajikistan [e.g. 14-19]. Also, some endemic species new to science have been described recently from this country [e.g. 20,21]. Considerable richness and uniqueness of the Tajik vascular flora is reflected by the rate of endemism. More than $30 \%$ of vascular plants species have very narrow distribution ranges and are regarded as endemics [10,22,23]. This is one of the most important reasons for recognizing the mountains of Middle Asia as one of the thirty-four hotspots of biodiversity [24] that needs special attention of botanists and conservationists [25]. Because of the considerable vulnerability to climate change, Tajikistan is regarded as one of the most sensitive region in the world [26]. Being exposed to a high risk of significant fluctuations in 
temperature and precipitation the vegetation and flora of Tajikistan is considerably threatened [27].

Despite not being rich in species, rock vegetation is considered very unique and interesting due to the harsh and extreme chasmophytic habitats that could serve as suitable biotope for many endemic and specialized plant species [28-32]. The mountain ranges of Tajikistan, especially those with relatively high precipitation like the Hissar Mts, are a refuge to a considerable number of stenochoric plant species that are sensitive to climate change [26,32-34]. The possible degradation processes like for example denudation or invasions of alien species make the documentation and classification of chasmophytic vegetation of Middle Asia very urgent. The phytosociological research of Tajik's vegetation is however still in the beginning stages. Recently, several papers concerning Tajik vegetation classification have been published [e.g. 35-38] with one devoted to solid rock faces communities of the alpine zone [39]. These associations were defined as the Campanulenion suballiance comprising of fourteen plant communities related to solid rock faces and fine crevices or fissures without or with very scarce amount of soil, often on very insolated southern walls. They differ considerably from Pentanemenion phytocoenoses which develop mainly on coarse crevices, rock ledges or clefts with much higher trophy because of considerable amount of deposited organic material.

Tajik's chasmophytic flora consists of many taxa geographically restricted only to this country or Middle Asia, like e.g. Achoriphragma pinnatifidum, Dionisia involucrata, Penthanema albertoregelia, Scutellaria hissarica, S. shugnanica, S. zapriagaewii, Sergia regelii, Silene shugnanica and many others. This floristic composition is significantly different when compared with other types of phytocoenoses. Because of the considerable structural differences between rock vegetation and other plant communities, a separate class was designed for communities of rock faces, fissures, clefts, crevices and rock ledges: Asplenietea trichomanis [40,41]. Many phytosociological surveys focused on rupiculous vegetation have been conducted recently in mountainous areas of Europe [e.g. 41-49], especially in the Mediterranean region [50-63]. However, due to considerably different species composition, they are not valuable for the presented study. Even the phytocoenoses noted in neighbouring areas of Asia have almost no common diagnostic species at the level of order or alliances [64-68].

Unfortunately, to date, in regions of the Middle Asia, for example in Tajikistan, Kyrgyzstan, Kazakhstan, and Uzbekistan, no phytosociological research of plant communities of saxatile vegetation have been conducted.
In works of synthesis, the rock vegetation has been described very generally as 'petryphyton' without using any classification or ordination methods [e.g. 69]. A few studies clarify questions of floristic, phytogeographical composition or zonation of rock or scree vegetation [70-72]. However, citing no relevés, they play a minor role in the description and interpretation of the rupicolous communities of Tajikistan.

The aim of the presented paper is to describe the communities of calcareous rock clefts and ledges of the Pamir-Alai mountains inhabiting mainly the alpine and subnival zones. The paper is a continuation of the phytosociological research of rock vegetation in Tajikistan [39]. Due to significant difference in microhabitat characteristic (coarse clefts and small ledges with considerable amount of soil) the presented group of phytocoenoses considerably differs from those inhabiting fine crevices of rock faces in Pamir Alai Mts [39]. A synopsis of the rock communities of the PamirAlai is proposed.

\section{Experimental Procedures}

\subsection{Study area}

The area of Tajikistan is ca. $143,000 \mathrm{~km}^{2}$ and extends

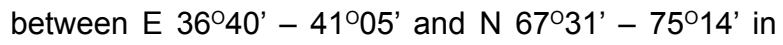
Middle Asia (Figure 1). The alpine landscape of high mountains is dominating within the country. More than $50 \%$ of the area is elevated above $3,000 \mathrm{~m}$. Despite the significant influence of mountainous microclimate, the subtropical climatic zone is stretching over the southern outskirts of Tajikistan. Northern parts are situated within the temperate climate zone [73]. The area of Tajikistan is characterized by relatively high insolation, low percentage of cloud cover, high-amplitude of annual temperatures, low humidity and low precipitation. In southwestern regions of Tajikistan, the average June temperatures are around $30^{\circ} \mathrm{C}$. In the temperate zone and alpine elevations the average temperatures during mid summer are between $9.7^{\circ} \mathrm{C}$ and $13.5^{\circ} \mathrm{C}$. Annual precipitation ranges in Tajikistan from ca. $70 \mathrm{~mm}$ (in the mountainous deserts of eastern Pamir and southwestern lowlands of the country) to ca. $600 \mathrm{~mm}$ (southern slopes of the Hissar Range). The limit of perpetual snow is at an altitude of $3,500-3,600 \mathrm{~m}$ in the western Pamir Alai Mts, raising up to about $5,800 \mathrm{~m}$ a.s.l. in the highest elevations of eastern Pamir [74,75].

The study was conducted fast in whole area of Tajikistan with the exception of eastern Pamir. Phytocoenoses of Eastern Pamirian Plateau considerably differ in floristic composition in comparison to the described vegetation from western Pamir Alai. 
Eastern outskirts of Pamir Alai are considered as separate geobotanical region with very harsh climate conditions in relation to continentality, aridity and precipitation. Those communities deserve special phytosociological research and will be analysed separately in the future. Several mountain ranges were investigated: Zeravshan Mts, Hissar Mts, Hazratishokh Mts, Darvaz Mts, Rushan Mts, Vanch Mts, Turkestan Mts, Peter I Mts, Yazgulem Mts and Karateginian Mts. All of them belong to Pamir Alai mountain system. The studied vegetation patches were located between 1,425 and $3,625 \mathrm{~m}$ a.s.l. (mean 2,286), They are developed on different types of rock substrate, with $\mathrm{pH}$ ranging between 7.1 and 8.8 .

Only few studies concerning geological structure have been issued for Tajikistan [e.g. 76]. The middle and higher parts of Hissar Mts are largely composed of extrusive rocks, mainly granite, granitoid and syenite. Some igneous outcrops are also found in Darwaz Mts, Kuraminian Mts and in western Pamir ranges. In Zeravshan and Turkestan Mts, the Cambrian and Sylurian sediments predominate. The rocks here are generally limestone (micrite limestone, bitumic limestone, marly limestone and dolomitic coral limestone), marble, dolomite, dolomitic shale, clay shale, phyllitic schist and argillaceous slate. Also several metamorphic rocks are presented within the study area. The most common are migmatic gneiss, conglomerates and metamorphic mudstones.

\subsection{Data and analyses}

The field research was conducted in 2010-2012. During the surveys, 101 phytosociological relevés were taken. The vegetation plot size was delimited in such a way as to represent full floristic composition of the phytocoenosis. It varied from 0.3 to $1 \mathrm{~m}^{2}$ depending on plant density and homogeneity of vegetation cover. For each vegetation plot, all vascular plants and cryptogams were recorded. Plant species were recorded according to the Braun-Blanquet cover-abundance scale. A 7-degree scale was used ( $r,+, 1,2,3,4,5$; [77]). Geographical coordinates, elevation above sea level, aspect and slope inclination were noted for each relevé. The rock type was determined by analysing the lithology, pore geometry, mineralogical components, texture, permeability, hardness and $\mathrm{pH}$ by proffesional geologist (see acknowledgments). Hydrogen ion concentrations were measured in aqueous rock solution using the ELMETRON CP-105 pH meter.

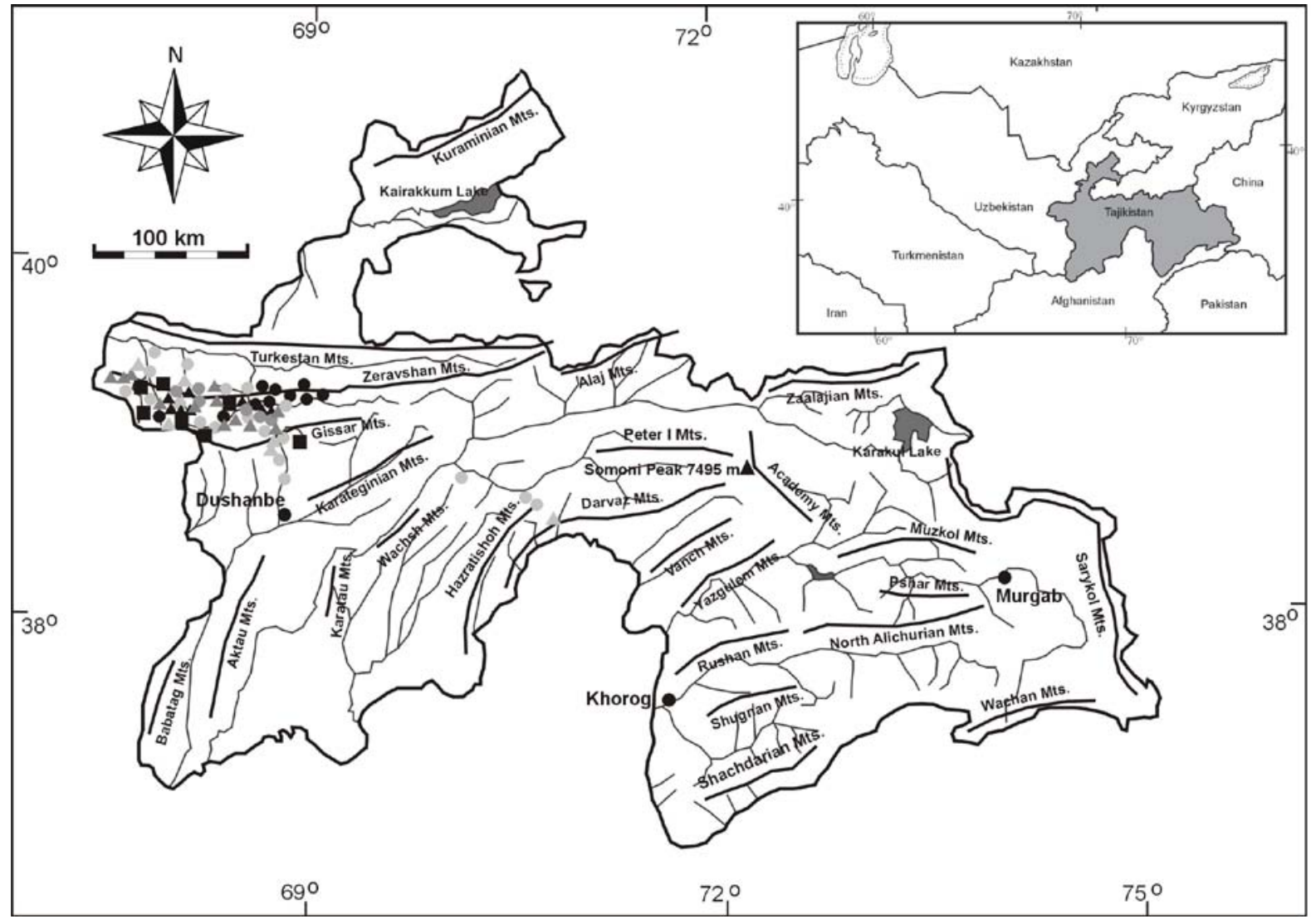

Figure 1. The area of Tajikistan with main cities, mountain ridges, rivers and lakes. Locations of the plant communities with symbols according to Figure 4. 
All relevés were stored in a database using the JUICE program [78]. A TWINSPAN analysis [79] was used to perform the preliminary classification of communities. As relevés data showed a clear unimodal response, allowing us to use a Detrended Correspondence Analysis (DCA) with the floristic data set (presenceabsence data, no downweighting of rare species) to check the floristic-sociological classification and to show the relationships between the groups. For the ordination, CANOCO for Windows 4.5 was used [80].

Vegetation classification follows the sorted table approach of Braun-Blanquet [77]. In the analytic tables (Figure 2,3), species constancies are given in classes I-V [81]. In case when the particular species was noted in less than 8 relevés, the absolute number of species occurrences was specified. Newly presented syntaxa, described as order, alliance or associations were proposed according to the International Code of Phytosociological Nomenclature [82]. When distinguishing and ranking the association, the works of Valachovič et. al. [42], Dimopoulos et. al. [53], Ermolaeva [59], Hein et. al. [64] and Noroozi et. al. [66] were taken into account. The association concept follows Willner [83]. The presented communities are arranged into a syntaxonomic overview at the end of the Results section.

Species nomenclature followed mainly Czerepanov [84]. Plant material collected during field studies was deposited in the Herbarium of Middle Asia Mountains, located in OPUN (Opole University, Poland) and KRA (Jagiellonian University, Poland).

\section{Results}

The number of taxa recorded in the relevés totals 77 , with 47 exceeding $2 \%$ constancy and 26 exceeding $5 \%$. The highest frequency vascular plant species included; Stipa zeravshanica (40 occurrences), Poa relaxa (35), Campanula incanescens (34), Asperula albiflora (23), Pentanema albertoregelia (22), Parietaria judaica (18), Artemisia rutifolia and Campanula lehmanniana (13), Achoriphragma pinnatifidum (12), Inula glauca (11), Saussurea ovata (11), Sergia regelii (11), Carex koshevnikovii (9) and Rhinactinidia popovii (7). Additionally 3 mosses were frequently observed: Bryum caespiticum (46 occurrences), Brachythecium albicans (44) and $B$. velutinum (7). Not all species noted in relevés were typical of rock face vegetation. In the studied plots, some ruderal species or plants typical for nitrophilous and often anthropogenic habitats were noted: Bromus tectorum, Conringia planisiliqua, Koelpinia linearis, Poa bulbosa and Sisymbrium loeselii. Also, species typical for agrocoenoses have been noted (Descurainia sophia) as well as plants typical of scree vegetation (e.g. Melica secunda, Scandix stellata, Silene brahuica, Sisymbrium brassiciforme) or rocky xerothermophilous swards (e.g. Pseudosedum condensatum). It is noteworthy that in the relevés obtained in the study area 6 moss species were found (e.g. Brachythecium albicans, B. velutinum, Bryum caespiticium, Encalypta vulgaris, Schistidium apocarpum, Syntrichia ruralis) albeit in low abundance.

As a result of the numerical classification of all the relevés for rock face phytocoenoses, 7 groups were distinguished. All groups were identified as associations (from the left to right respectively in Figure 4): Pentanemetum albertoregeliae, Asperulo albiflorae-Stipetum zeravshanicae, Inuletum glaucae, Achoriphragmetum pinnatifidi, Paraquilegietum anemonoidis, Rhinactinidietum popovii and Saussureaetum ovatae. Six of the associations listed above have been described for the first time.

The species composition of the researched plots determines the classification of all seven communities into Campanuletalia incanescentis within the Asplenietea trichomanis class. This order includes phytocoenoses with high constancy and abundance of chasmophytic taxa with Irano-Turanian distributional range. The most frequent species constituting the communities are Campanula incanescens, Poa relaxa, Campanula lehmanniana, Sergia regelii, Scutellaria orbicularis and Artemisia rutifolia. These associations are spreaded throughout Pamir Alai Mts, from the colline zone to the highest subnival elevations with chasmophytic vegetation (ca. 4,500 $\mathrm{m}$ a.s.l.). The phytocoenoses occur on various types of substrata, with alkaline or acidic reaction, such as limestone, dolomite, marble, granite, syenite, gabro, schist, conglometare and gneiss. Campanula incanescens can grow on alkaline, neutral and acidophilous substrata. Due to significant differences in habitat conditions and as a result in species composition (inclination, insolation, crevice size, altitudinal amplitude, soil amount), it is indispensable to distinguish several or even more groups within the order. All described associations must be defined as members of the Asperulo albiflorae-Poion relaxae alliance Nobis et. al. 2013 [85]. Within this syntaxon the associations of rock faces, fissures and small ledges of alpine and subnival zones are classified. Diagnostic species for the alliance are: Artemisia rutifolia, Asperula albiflora, A. czukavinae, Lophanthus virescens and Poa relaxa. The phytocoenoses of the Asperulo albiflorae-Poion relaxae are distributed mainly in western Pamir Alai Mts and less frequently in the Kuraminian Range (SW Tian-Shan) and eastern Pamir. The altitudinal amplitude of these communities is generally between 1,700 and $2,600 \mathrm{~m}$. 


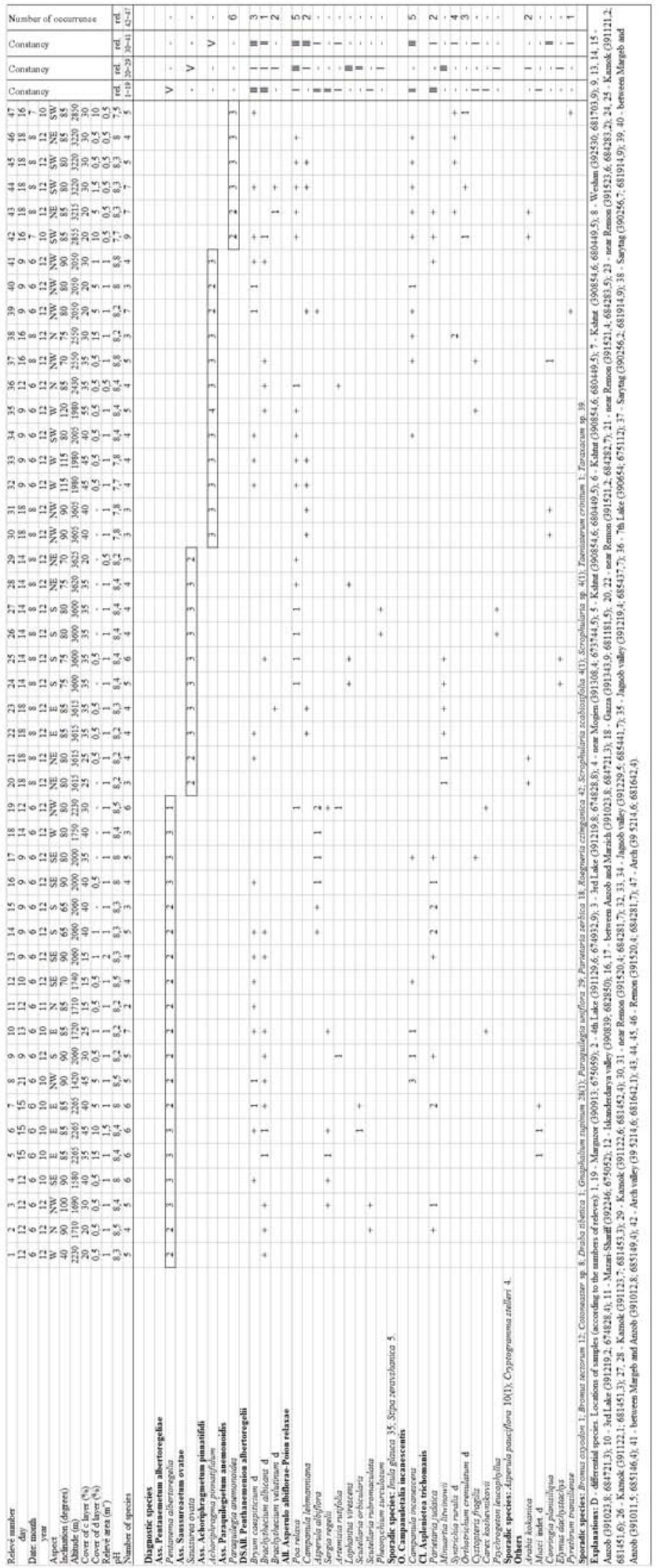




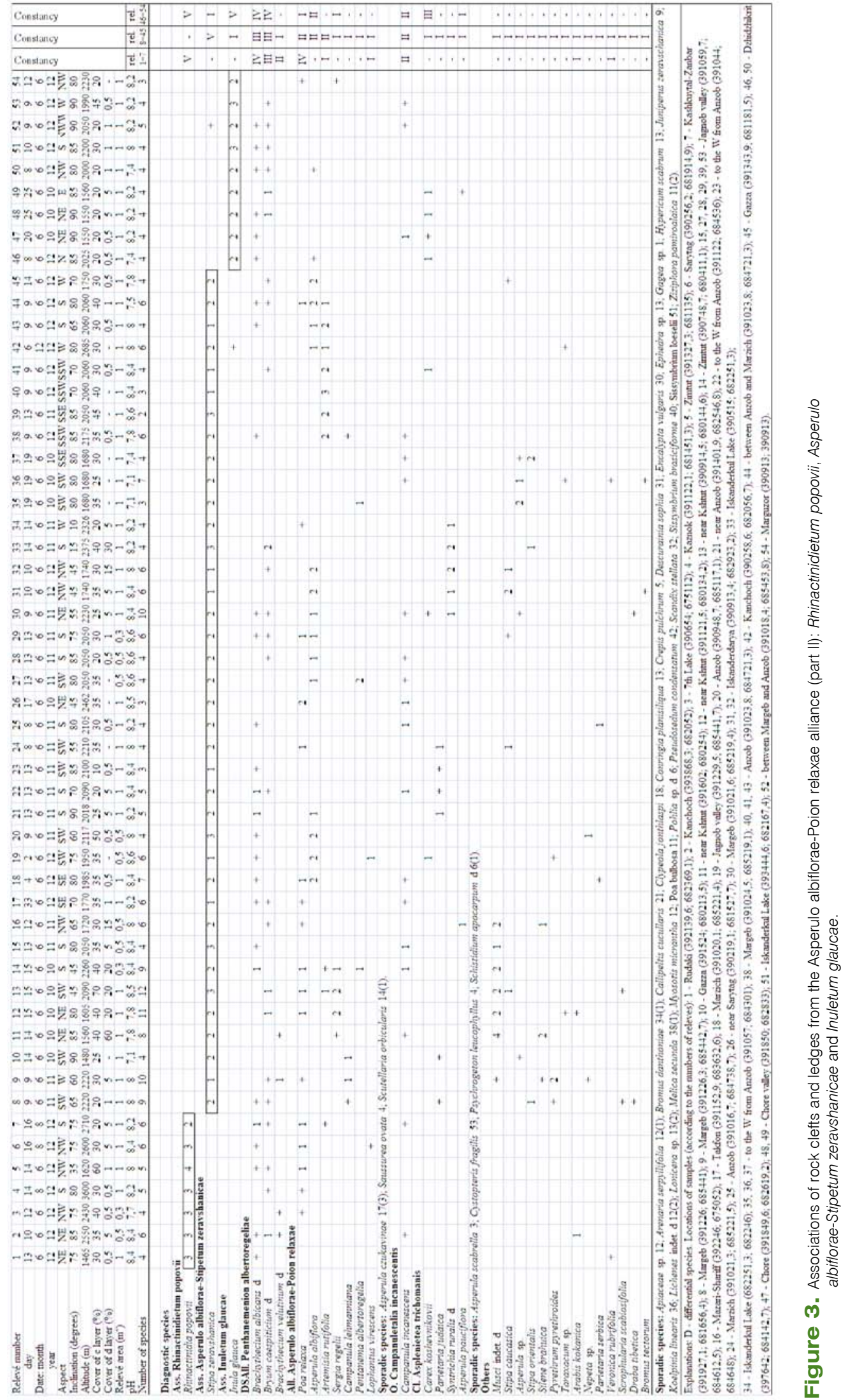




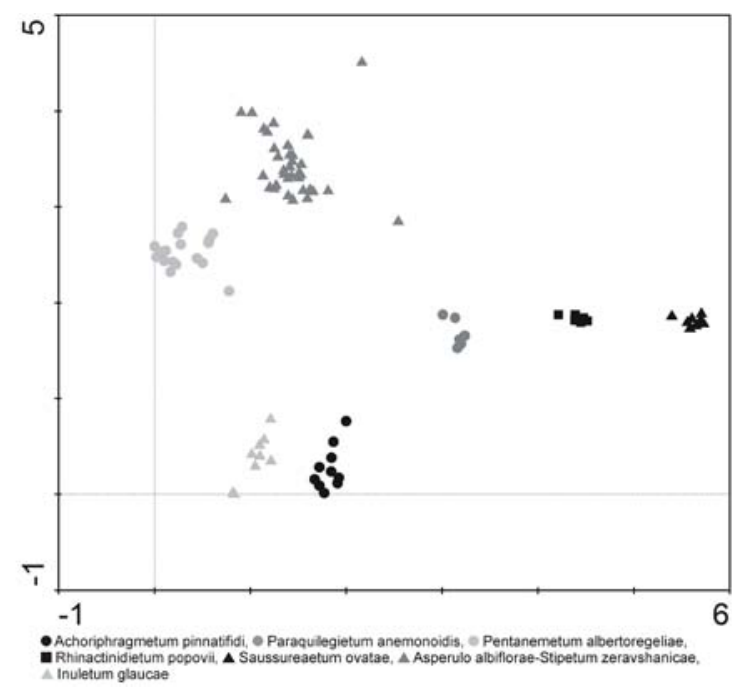

Figure 4. DCA ordination for all samples of rock clefts and ledges communities ( $N=101)$.

\subsection{Syntaxa of rock clefts and ledges of the alpine and subnival zone in Tajikistan}

\section{Suballiance: Pentanemenion albertoregeliae suball. nova}

Nomenclatural type: Pentanemetum albertoregeliae hoc loco

Diagnostic species: Pentanema albertoregelia, Brachythecium albicans, B. velutinum, Bryum caespiticum

This group of associations could be defined by floristic composition and habitat conditions. As was mentioned above, the plant communities from Pentanemenion suballiance occupy rock ledges and coarse crevices of rock faces with considerable amount of soil sediment, so in places of relatively high nutrient availability (Table 1). This trophy conditions has the consequences in species structure of the phytocoenoses. Among dominant species Inula glauca, Pentanema albertoregelia, Rhinactinidia popovii, Saussurea obovata or Stipa zeravshanica reach the highest frequencies.

\section{Pentanemetum albertoregeliae ass. nova}

Typus relevé: Figure 2, relevé 3

\section{Diagnostic species: Pentanema albertoregelia}

The phytocoenoses of Pentanemetum albertoregeliae have been found in several locations in Zeravshan Mts, mainly in the Seven Lakes, Veshan, Pastrud-Daria, Kshtut, Jagnob and Iskander-Daria River valleys within the central and western Zeravshanian geobotanical subregions (Figure 6). Pentanema albertoregelia is a species spread throughout Pamir Alai and western TianShan mountains [9], so the association is supposed to have wider distribution range than the Zeravshanian region. It was found in the alpine zone at the relatively low altitudes of 1,420 to $2,265 \mathrm{~m}$ a.s.l. (mean approx. 1,900; Figure 2,5). The association prefers limestone and dolomite rocks ( $\mathrm{pH} 8.0$ - 8.5) with coarse crevices and clefts. The community was found mainly on the southeastern, eastern and southern expositions with almost vertical inclinations (mean approx. $80^{\circ}$ ). The association is characterised by moderate abundance of vegetation cover due to scarce contribution by the species. The total cover of the herb layer generally was between 13 and $45 \%$ with mean value of approx. $30 \%$ (Figure 2 and 5). As well, the phytocoenosis was characterized by a moderate number of species as far as rupicolous vegetation is concerned; having 2 to 7 taxa (mean value approx. 3) in one relevé. Mosses insignificantly contribute to the association and their total cover does not exceed $8 \%$ with the mean value of about $3 \%$ (Figure 5). Among the vascular plants the highest values of constancy and abundance have: Campanula incanescens, Parietaria judaica and Asperula albiflora. In moss layer, the most important contributors are Brachytecium albicans and Bryum caespiticum.

\section{Saussureaetum ovatae ass. nova}

Typus relevé: Figure 2, relevé 22

Diagnostic species: Saussurea ovata

Saussurea ovata is a broadly distributed rupicolous species, known generally from alpine and subnival zone of Pamir Alai and Tian-Shan [10]. In Tajikistan it was formerly reported only from the eastern Pamir Alai, vicinity of Kara-Shura settlement. During our research the association built by Saussurea ovata was found at several sites in subnival elevations in Chimtarga Massif (around Mutne Lake) and in Jagnob valley. The phytocoenosis has been found almost exclusively on alkaline limestones and marly limestone $(\mathrm{pH}$ 8.2-8.4). The association prefers coarse clefts and ledges with significant soil amount. Sometimes the association has been noted in shaded places. The phytocoenosis develops on relatively high elevations in subnival zone, within a narrow altitudinal range with a mean value of approx. 3,600 m a.s.l. The community develops on steep or slightly sloping rock walls (mean inclination of approx. $80^{\circ}$ ). Saussureaetum ovatae generally inhabits northeastern and southern expositions. The mean value of herb layer total cover is about $35 \%$ ranging from 16 to $34 \%$ (Figure 2 and 5). Mosses entered the plots rarely and their coverage was approximately $1 \%$. The most abundant and constant vascular plant species within the phytocoenosis of Saussureaetum ovatae are: Poa relaxa and Minuartia litwinowii. Observed mosses are: Brachytecium albicans, B. velutinum and Bryum caespiticum. 

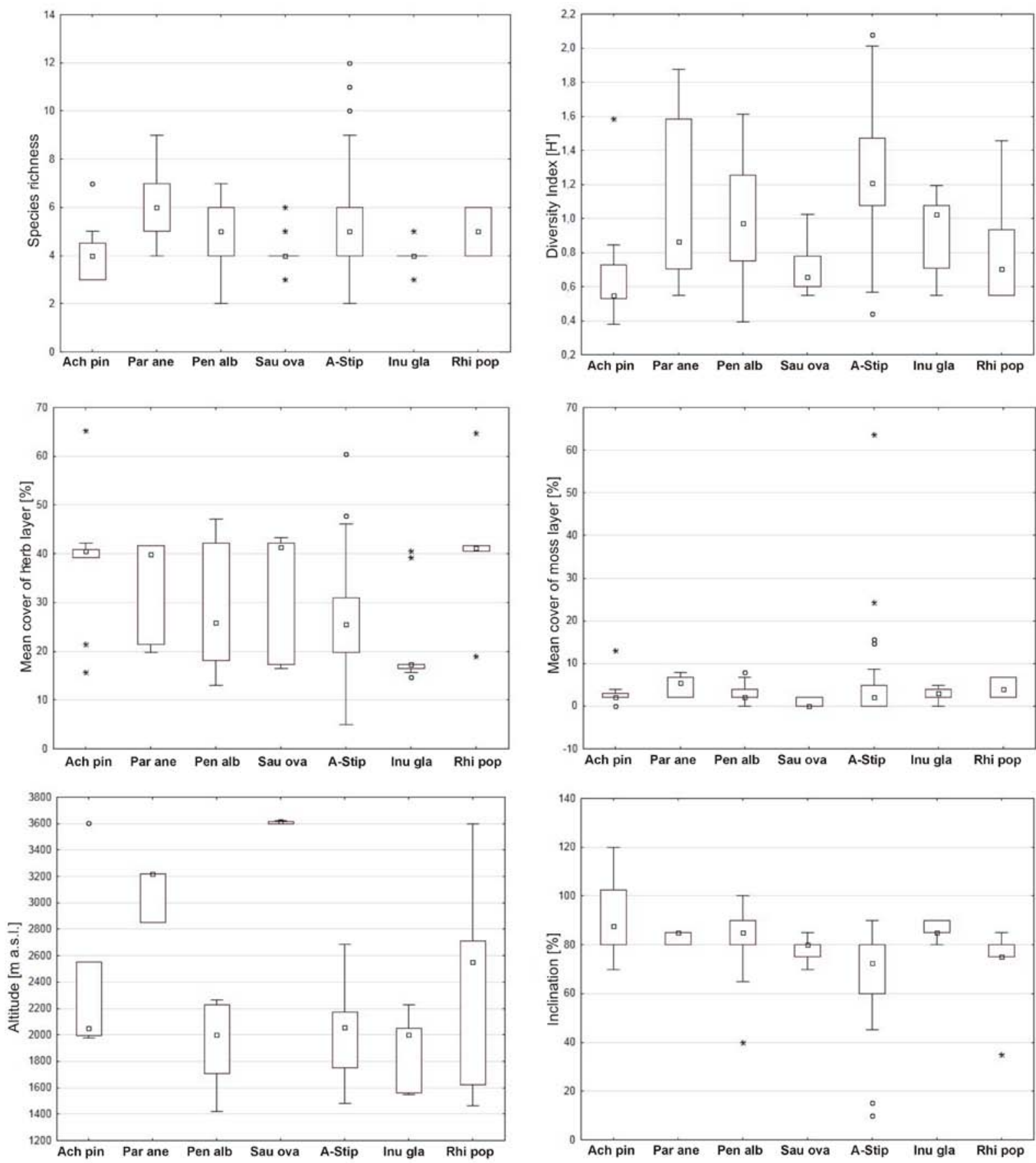

Figure 5. Species richness and diversity, cover values of herb and moss layer, altitudinal distribution and cliff inclinations of the researched associations: Achoriphragmetum pinnatifidi (Ach pin), Paraquilegietum anemonoidis (Par ane), Pentanemetum albertoregeliae (Pen alb), Saussureaetum ovatae (Sau ova), Asperulo albiflorae-Stipetum zeravshanicae (A-Stip), Inuletum glaucae (Inu gla), Rhinactinidietum popovii (Rhi pop).

Achoriphragmetum pinnatifidi ass. nova

Typus relevé: Figure 2, relevé 32

Diagnostic species: Achoriphragma pinnatifidum

Achoriphragma pinnatifidum is a chasmophytic species broadly distributed across the alpine and subnival zones of the Pamir Alai, Tian-Shan and the western Altay (in chineese Dzhungaria; [4]). In Tajikistan, Achoriphragma pinnatifidum is commonly found in Turkestan, Zeravshan, Hissar, Peter I and Rushan ranges (Figure 1). The association of Achoriphragma pinnatifidum was found in several sites in the alpine and subnival elevations (Figures 5,6) of Seven Lake, Inskander-Daria, Jagnob, 


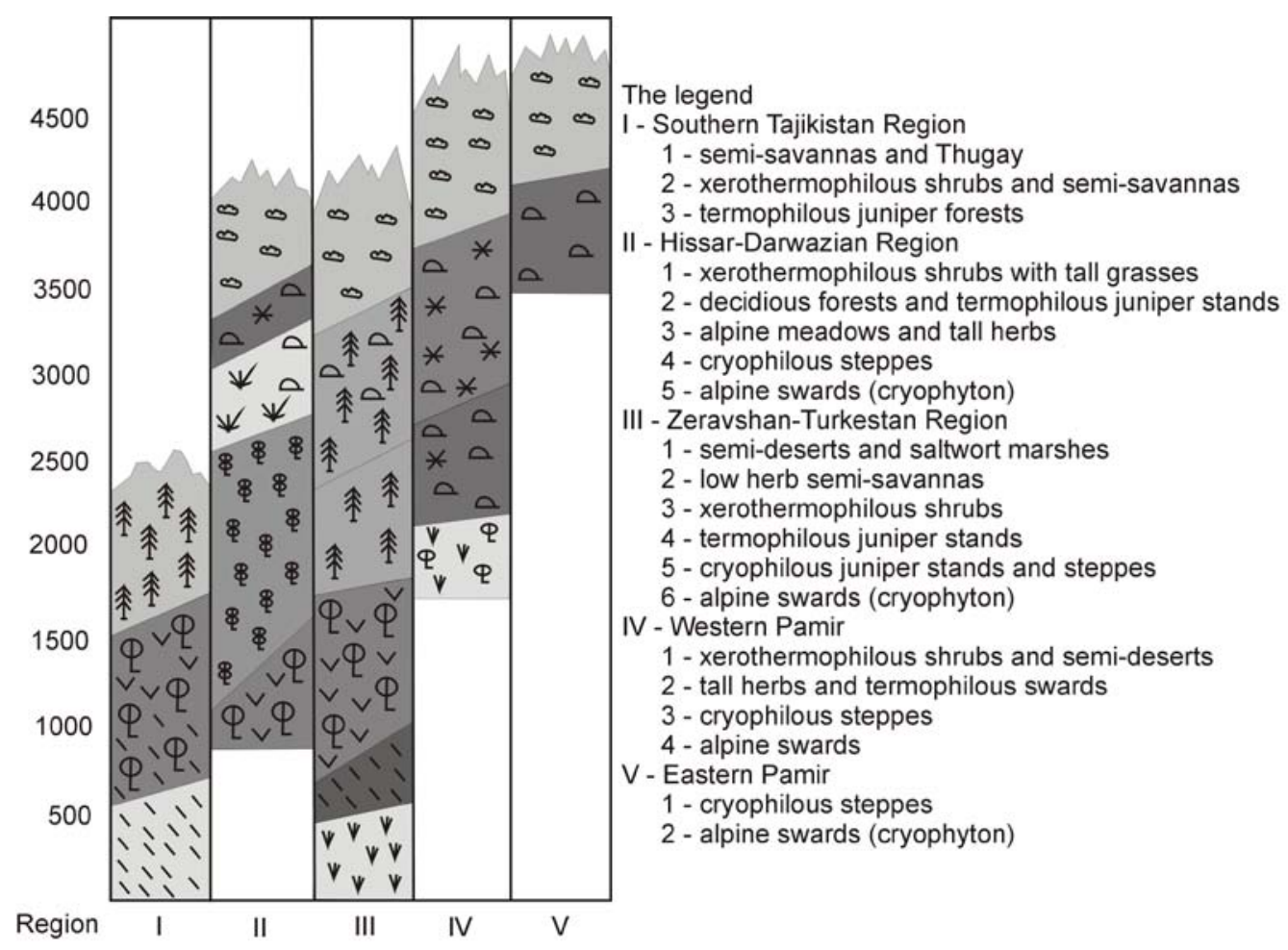

Figure 6. Zonation of vegetation in Tajikistan.

Kara-Kul and Pastrud-Daria River valleys. The phytocoenosis has been found almost exclusively on alkaline limestone and marly limestone ( $\mathrm{pH} 7.7-8.8)$. This association prefers fissured rocks, sometimes friable. The populations of Achoriphragma pinnatifidum inhabit large crevices and coarse clefts with considerable amount of soil substrate. The phytocoenosis develops on relatively high elevations in alpine and subnival zones, at an altitude of 1,980 to $3,605 \mathrm{~m}$ a.s.l. (mean approx. 2,400). The community develops on steep and sloping walls, however it was also observed under the overhanging rock benches or on almost flat terraces or stones. The mean inclination value for the sampled plots was approx. $90^{\circ}$, ranging from $70^{\circ}$ to $120^{\circ}$ (Figure 5). Achoriphragmetum pinnatifidi inhabits generally the western and northwestern expositions. The total cover mean value of herb layer is relatively high ranging between 15 and 65\% (mean approx. 40\%; Figure 5). Contribution of mosses to the community was rare and did not exceed significant values (approximately $3 \%$ on average). Only in one case, the moss layer was ca. $13 \%$ due to atypical habitats - the rock ledge with significant soil amount and humidity. The most abundant and constant species within the phytocoenosis of Achoriphragmetum pinnatifidi are: Poa relaxa, Campanula incanescens, $C$. lehmanniana, from vascular species and Brachytecium albicans and Bryum caespiticum from mosses.

\section{Paraquilegietum anemonoidis ass. nova}

Typus relevé: Figure 2, relevé 44

Diagnostic species: Paraquilegia anemonoides

The diagnostic species is a typical saxatile plant with extent geographical range embracing Pamir Alai, TianShan, Altay, Elburs, Himalaya, Hindukush, Karakorum ranges as well as Pamir and Tibet plateaus; Figures 1,6). The plots of the association have been found in Jagnob and Arch River valleys (central Zeravshan range) within the alpine and subnival zones at altitudes from 2,850 to 3,220 m a.s.I. (mean approx. 3,100; Figure 5). This community inhabits eastern, southwestern and northeastern rock faces with almost vertical inclinations (mean approx. $85^{\circ}$ ). It prefers coherent rocks with medium-sized crevices and clefts with moderate amount of soil substrate. The phytocoenoses were observed on dolomite and limestone with alkaline reaction ( $\mathrm{pH}$ between 7.5 and 8.3). The association is characterized by a moderate herb cover value of approx. 35\% (between 20 and 40\%). Sampled plots have medium number of species, between 4 and 9 (mean value approx. 6 per relevé). Also the moss layer cover is considerable and slightly higher than in other associations, with $5 \%$ value on average (Figure 5). Apart from the diagnostic Paraquilegia anemonoides, several other chasmophytes have been observed within the plots, e.g.: Campanula lehmanniana, C. incanescens, 
Poa relaxa and Arabis kokanica. Additionally, three mosses contribute to the association: Brachytecium albicans, B. velutinum, Bryum caespiticum.

\section{Rhinactinidietum popovii ass. nova}

Typus relevé: Figure 3, relevé 2

Diagnostic species: Rhinactinidia popovii

The distribution of the association is fully compliant with the range of the diagnostic species. The Rhinactinidia popovii is widely distributed species in subalpine and alpine zones of Pamir Alai and Tian-Shan mountain systems [9]. Plots of the phytocoenosis has been found in Kara-Kul, Kshtut, Iskander-Daria, Seven Lakes and Kashkuytal-Zanbar River valleys. The phytociological research conducted in this area confirm, that the species built its own association developing on alkaline rock substrates ( $\mathrm{pH}$ 7.7-8.4), mainly limestone (marly limestone), marble and dolomitic shale. The phytocoenosis develops on medium sized crevices ledges, wall corners and coarse clefts. The association develops on different elevations in subalpine, alpine and rarely subnival zones (Figures 5,6), within the altitudinal range between 1,460 and $3,600 \mathrm{~m}$ a.s.l. (mean approx. 2,400 ). The community develops generally on steep rock walls, however frequently uses sloping parts or even almost flat sections of rock ledges. The noted inclinations were between $35^{\circ}$ to $85^{\circ}$ (mean value approx. $70^{\circ}$; Figure 5). Rhinactinidietum popovii prefers generally northwestern and northeastern exposition (Figure 7). Within the sampled plots, between 4 and 6 species were noted (mean approx. 5), so as majority of the rupicolous vegetation, the Rhinactinidietum popovii should be classified as species poor community. Despite the scarcity of species, the association is characterized by relatively high value of total cover of vascular plants in the phytocoenoses plots. It could reach up to $65 \%$ with the mean value of approx. $40 \%$ (Figure 5). Relatively insignificant is the total cover of moss layer, having a mean value below $4 \%$. Among the species occurring with higher constancy are Campanula incanescens and Poa relaxa. As regards to mosses, five taxa have been noted: Brachytecium albicans, B. velutinum, Bryum caespiticum, Syntrichia ruralis and Pohlia sp.

\section{Asperulo albiflorae-Stipetum zeravshanicae M. Nobis,} A. Nowak et A. Nobis 2013

\section{Diagnostic species: Stipa zeravshanica}

The phytocoenoses of Asperulo albiflorae-Stipetum zeravshanicae have been found quite frequently in the central section of Zeravshan range; mainly in Jagnob, Iskander-Daria, Seven Lakes Valley, Archamaidan and Kshtut River Valleys. The association is distributed in montane, subalpine and alpine zone (Figure 6) at
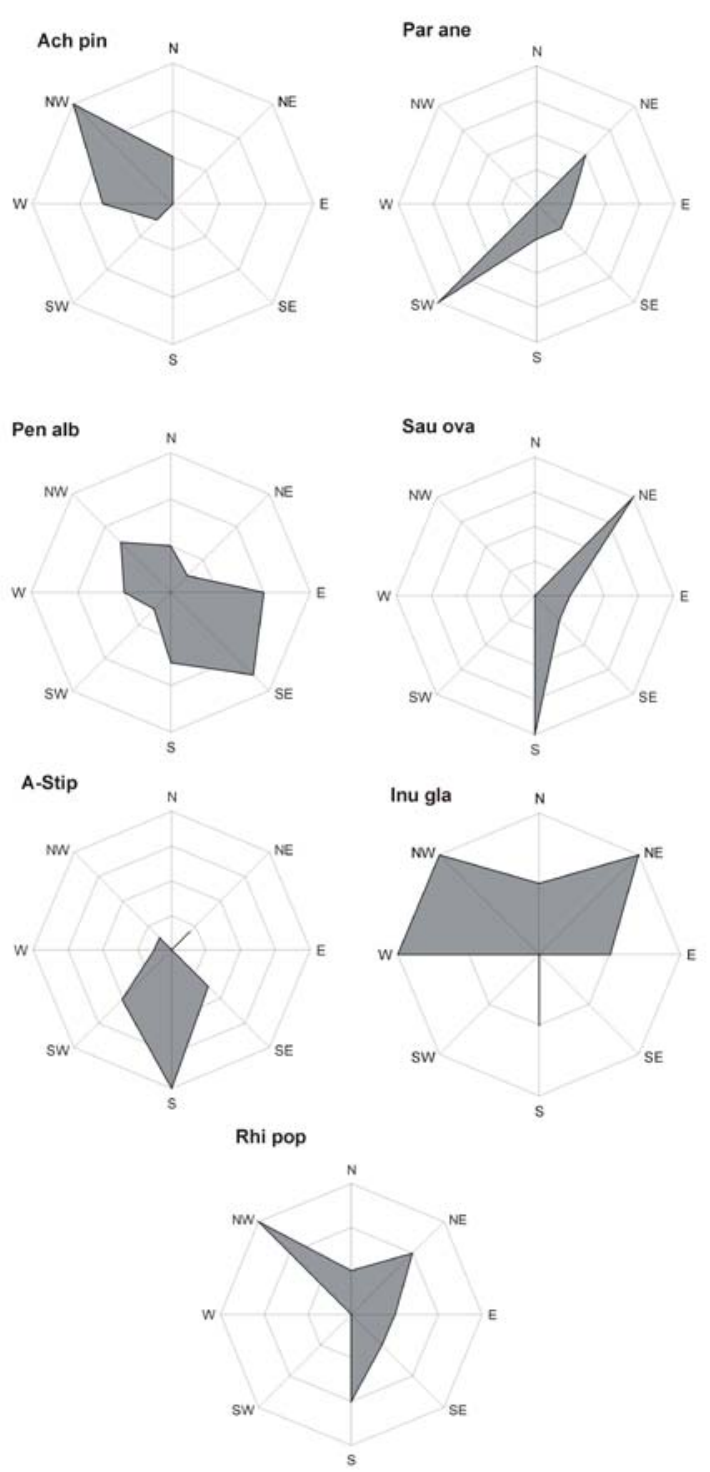

Figure 7. The exposition preferences of the researched associations. Explanations of plant communities abbreviation as in Figure 5. N - north, NE - north-east, E - east, SE - south-east, S - south, SW - south-west W - west, NW - north-west.

altitudes from 1,480 to $2,685 \mathrm{~m}$ a.s.l. (mean approx. 2,000; Figure 5). This association prefers rock ledges and coarse clefts on steep walls, often within the rivers breakthroughs. In few cases the plots have been also noted on rocky taluses on steep slopes. The phytocoenoses were observed on limestone and dolomite substrates with $\mathrm{pH}$ between 7.1 and 8.6 [85]. The association is found on different expositions (mainly southern, southeastern and southwestern). Due to different relief of ledges and shelves, the sites Asperulo albiflorae-Stipetum zeravshanicae have significantly diversified sloping rate, from $10^{\circ}$ to $80^{\circ}$ (mean approx. 
$\left.65^{\circ}\right)$. The species entering the vegetation plots are moderately abundant. The total cover of the herb layer was between 5 and $60 \%$ with a mean value of approx. $27 \%$. The phytocoenoses are characterized by moderate number of species in comparison to other chasmophytic vegetation. In a single vegetation plot, 3 to 12 species have been found (mean value ca. 6). The total cover of moss layer in the phytocoenoses is relatively high reaching up to $60 \%$ with a mean value of about $6 \%$ (Figure 5). Among the vascular plants, excluding the diagnostic species, the most constant and abundant are e.g.: Asperula albiflora, Poa relaxa, Artemisia rutifolia and Stipa caucasica. The most frequent mosses are Brachytecium albicans and Bryum caespiticum (Figure 3).

\section{Inuletum glaucae ass. nova}

Typus relevé: Figure 3, relevé 51

Diagnostic species: Inula glauca

The phytocoenoses of Inuletum glaucae have been spotted sporadically in the central section of Zeravshan range, at few sites in Chore, Jagnob, Iskander-Daria and Dzhidzhikrut River valleys. The diagnostic species belongs to endemics of Pamir Alai and is known from several sites within the montane to alpine zones of Zeravshan Hissar, Darvaz, Babatag and Peter I ridges [9]. It was also found in two places in the western Pamir. The association is distributed across montane and subalpine zones at the relatively low altitudes of 1,550 to 2,230 m a.s.I. (mean approx. 1,900; Figures 5, 6 and 7). As the Achoriphragmetum pinnatifidi the association prefers fissured rocks with large crevices and coarse clefts. Plots of the association were found in wall corners, sometimes shady, but in all cases with considerable amount of soil substrate. The phytocoenosis inhabits the limestone and dolomite rocks of alkaline reaction ( $\mathrm{pH} 7.4-8.2$ ). The phytocoenosis was observed generally on shaded walls with northern, northeastern and northwestern expositions and almost vertical inclinations (mean approx. $85^{\circ}$ ). The species constituting the vegetation plots are generally not abundant. The total cover of the herb layer generally was between 15 and $40 \%$ with mean value of approx. $20 \%$. The phytocoenosis is characterized by low number of species in comparison with other saxatile vegetation in Tajikistan, having between 3 and 5 species in one relevé (mean value ca. 4). The total cover of mosses is insignificant and did not exceed $5 \%$ with a mean value of about 3\% (Figure 5). Among the vascular plants the highest values of constancy and abundance are: Poa relaxa, Campanula incanescens and Carex koshevnikovii. The most frequent mosses are Brachytecium albicans and Bryum caespiticum.

\subsection{Synopsis of syntaxa}

Based on this study, we propose the following classification of rock clefts and ledges vegetation of the alpine and subnival zone in Tajikistan:

Class: Asplenietea trichomanis (Br.-BI. in Meier et Br.-BI. 1934) Oberdorfer 1977

Order: Campanuletalia incanescentis M. Nobis, A. Nowak et A. Nobis 2013

Alliance: Asperulo albiflorae-Poion relaxae M. Nobis, A. Nowak et A. Nobis 2013

Suballiance: Pentanemenion albertoregeliae suball. nova

1. Pentanemetum albertoregeliae ass. nova

2. Saussureaetum ovatae ass. nova

3. Rhinactinidietum popovii ass. nova

4. Asperulo albiflorae-Stipetum zeravshanicae M. Nobis, A. Nowak et A. Nobis 2013

5. Achoriphragmetum pinnatifidi ass. nova

6. Inuletum glaucae ass. nova

7. Paraquilegietum anemonoidis ass. nova

\begin{tabular}{|c|c|c|c|c|c|c|}
\hline Community & Soil amount & Crevice type & Rock type & Insolation & Main exposition & Altitude \\
\hline Pentanemetum albertoregeliae & M & M & C & $\mathrm{H}$ & SE,NW & M \\
\hline Saussureaetum ovatae & M & $\mathrm{M} / \mathrm{C} / \mathrm{L}$ & C & $\mathrm{H}$ & NE,S & $\mathrm{H}$ \\
\hline Rhinactinidietum popovii & M & $\mathrm{M} / \mathrm{C} / \mathrm{L}$ & C & M & W,NW & $\mathrm{M} / \mathrm{H}$ \\
\hline $\begin{array}{l}\text { Asperulo albiflorae-Stipetum } \\
\text { zeravshanicae }\end{array}$ & $\mathrm{M} / \mathrm{H}$ & $\mathrm{C} / \mathrm{L}$ & $\mathrm{C} / \mathrm{N}$ & $\mathrm{H}$ & NW,NES & M \\
\hline Achoriphragmetum pinnatifidi & $\mathrm{M} / \mathrm{H}$ & $\mathrm{M} / \mathrm{C} / \mathrm{L}$ & C & M & NW & M \\
\hline Inuletum glaucae & M & $\mathrm{M} / \mathrm{C}$ & C & M & NW,NE,W & M \\
\hline Paraquilegietum anemonoidis & M & $\mathrm{M} / \mathrm{C}$ & C & M & SW,NE & $\mathrm{H}$ \\
\hline
\end{tabular}

Table 1. Principal ecological characteristics of the typified association habitats.

Explanations: Soil amount: $M$ - medium, H - high; Crack type: F - fine, $M$ - medium, C - coarse, L - ledge; Rock type: C - calcareous, $\mathrm{N}$ - neutral; Insolation: $\mathrm{H}$ - high, $\mathrm{M}$ - moderate. Exposition: $\mathrm{W}$ - western, $\mathrm{S}$ - southern, $\mathrm{E}$ - eastern, $\mathrm{N}$ - northern; Altitude: $\mathrm{H}$ - high, $M$ - medium, L - low 


\section{Discussion}

\subsection{Position of the described associations in the syntaxonomical system of rock vegetation in Tajikistan}

Undoubtedly, all of the described phytocoenoses, due to the considerable frequency and abundance of diagnostic taxa as well as species of IranoTuranian distributional type, have to be classified in the Campanuletalia incanescentis order. The order includes phytocoenoses characterized by a high share of chasmophytic and rupicolous taxa like Artemisia rutifolia, Campanula incanescens, C. lehmanniana, Poa relaxa, Scutellaria orbicularis, Sergia regelii and Stipa zeravshanica. Many of the species typical for this syntaxon are unique endemics of Tajikistan or Middle Asia; however, there are also species widely distributed throughout the Irano-Turanian province. For example, Campanula incanescens occurs on screes within a considerable altitudinal range, from 400 up to $3600 \mathrm{~m}$ a.s.I. throughout all the main mountain ranges of Middle Asia (e.g. Tian-Shan, Kopet-Dag, Pamir-Alai, Pamir) and also in the Iranian province (Elburs, Zagros Mts) $[9,86]$. Due to floristic composition as well as habitat conditions (crevice size, altitudinal amplitude, soil amount) all seven presented plant associations ought to be included in the Asperulo albiflorae-Poion relaxae Nobis et. al. 2013 alliance. The diagnostic species of that syntaxon are frequently spotted plants in the described plots (Asperula albiflora, A. czukavinae, Lophanthus virescens and Poa relaxa). The phytocoenoses of the Asperulo albifloraePoion relaxae are scattered generally across the alpine and subnival zones of the western Pamir-Alai Mts and less frequently on the Kuraminian (SW Tian-Shan) and Pamir ranges. These plots are considerably different in comparison to the phytocoenoses inhabiting lower elevations with higher amounts of precipitation, mainly in the Hissar and Darwaz Mts. A reconnaissance survey of rock communities of the montane and colline zones of these ranges shows a significantly distinct species composition. The apparent domination in many plots and considerably high constancy of Carex koshevnikovii is the crucial difference. The phytocoenoses consist also of e.g. Dionisia involucrata, Scutellaria adenostegia, S. hissarica, S. schugnanica, S. zaprjagaevii or Tylosperma lignosa.

The Asperulo albiflorae-Poion relaxae alliance, according to the rock surface microrelief and related soil amount, may be divided into two groups. The first (Campanulenion lehmannianae Nowak et. al. 2013) consists of an aggregation of species preferring firm and solid rocks with very fine fissures. These sites are often almost completely bare, with very little or no soil sediment. Also, the moss layer is quite scarce in terms of the number and abundance of species. The most abundant and frequent vascular plants are Campanula lehmanniana, Silene samarcandensis, Scutellaria orbicularis, Scutellaria rubromaculata and Sergia regelii [39]. The second group is presented here as the associations from the Pentanemenion suballiance. They prefer coarse crevices and ledges containing a considerable amount of soil substrate and consequently the species composition is considerably different. Phytocoenoses were dominated by e.g. Pentanema albertoregelia, Inula glauca, Rhinactinidia popovii, Saussurea ovata.

\subsection{Community distinctiveness, chorology and richness}

Mountains are especially rich in endemic species, because they are often geographically isolated and have extremely diverse environmental conditions $[28,31,87]$. Even if in some areas the rock habitats do not shelter endemic species, they could support endemic associations (e.g. Serra de Monchique Mts in Portugal for Sileno melliferae-Ranunculetum bupleuroidis, Halimio calycini-Ericetum australis [60]). The specificity of Tajikistan is an extremely large area of various types of rock habitats. This diversity of ecological niches could serve as a biotope for the numerous groups of endemics. Partially, this is a result of the extra-zonal character of rocky habitats and the very different conditions in terms of humidity, type of rock substrate, insolation, temperature and inclination $[23,39]$. Despite this extreme richness of petrophytic flora and its uniqueness, so far few studies concerning saxatile vegetation in Tajikistan have been published.

The distinct flora which constitute the chasmophytic vegetation in Tajikistan is classified in a separate vegetation order (Campanuletalia incanescentis) in the class Asplenietea trichomanis. This order includes petrophytic phytocoenoses consisting of taxa with an Irano-Turanian disributional range. There is nothing extraordinary about considerable richness and distinctiveness of saxatile vegetation in the IranoTuranian or Mediterranean regions. This is known from studies in smaller areas like Greece [53]. It is apparent that the petrophytic communities from Campanuletalia incanescentis are completely distinct in floristic structure from any other rock vegetation in southern Europe or southern Asia. Comparing the constant and abundant taxa of rock vegetation in Tajikistan with communities of other mountains in adjacent areas, it is difficult to find any species in common $[55,62,68]$. Even in the nearby Caucasus Mountains, the taxa noted in phytocoenoses of the order Androsacetalia multiflorae Br.-BI. in Meier 
and Br.-BI. 1934 (alliances Thalictro foetidi-Asplenion Onipchenko and Gorbachevskaya 2002, Gypsophilion tenuifoliae Onipchenko and Gorbachevskaya 2002) have no species in common [59]. Obviously, there is no share of the same non-sporadic species in the communities reported from the eastern Mediterranean, Anatolian and south Siberian areas [53,63,64,67]. One of the reasons for this high degree of separation is the difference in climatic conditions. The Pamir-Alai is mainly influenced by a Mediterranean-type climate, however, of relatively high continentality. At alpine and subnival elevations the topoclimate is very severe and harsh due to temperature amplitudes, wind velocity or water availability. This is one of the main factors influencing the uniqueness of flora and endemism. In comparison with other types of vegetation, petrophytic phytocoenoses have a significantly higher rate of endemism and more stenochorous species. This brings a number of floristically well-defined syntaxa with small, often endemic range within one country [39,42,60]. However, as opposed to the associations from Campanulenion suballiance, within Pentanemenion the majority of diagnostic species have a wider distribution. Most of them occur in 3-4 or more mountain ranges in central or even southwestern Asia. To this group belong Pentanema albertoregelia and Saussurea ovata, known mainly from Pamir-Alai and Tian-Shan, and Rhinactinidia popovii distributed across all of Middle Asia up to the Altay in southern Kazakhstan. An even wider range of occurrence have Achoriphragma pinnatifidum and Paraquilegia anemonoides, spread not only throughout the Middle Asian ranges, but distributed also in mountains of western China, the southwestern Himalayas, Afghanistan and Iran [4,5,9,10]. Only two out of seven described associations are defined by the endemic taxa of western Pamir-Alai: Asperulo-Stipetum zeravshanicae, with the main characteristic species known only from the central section of the Zeravshan mountains [85], and Inuletum glaucae, inhabiting rock clefts mainly in the ranges of the Zeravshanian and Hissaro-Darvasian geobotanical regions with several outposts stationed in the immediate neighbourhood.

The difference between highly endemic Campanulenion associations and moderately endemic Pentanemenion communities may be caused by soil amount and nutrient availability. The lower the soil deposition, the more harsh and severe environmental conditions and the higher consequent floristic endemism. As we know, 'rocky' habitats without stabilised soil cover or with only underdeveloped humic substrates play the role of isolated terrestrial islands, where genetic drift and founder effect work effectively and cause a high rate of endemism [66,88-92]. In Tajikistan's scree, ca. 1,230 of 1,486 endemic plants of the country are confined to rock and taluses vegetation [23]. This kind of stenochory of chasmophytic plant communities is also known from many other mountainous areas, especially with Mediterranean-type climates. It has been observed in the Bokkoya Mountains in Northern Morocco [93,94], in Gibraltar [95], in Crete and mainland Greece [53], in Caucasus and the mountains of Central Asia [30,59], in the Taurus Mts in Turkey [55,64] and Galicia in Spain [51].

\subsection{Ecological features determining the floristic composition of the plant communities}

The detrended correspondence ordination of all samples clearly segregates the plant communities. From left to the right, the main discrimination factor seems to be altitude. The phytocoenoses of the lowest elevations (Pentanemetum albertoregeliae and Inuletum glaucae) are grouped on the left, while on the right the communities from the highest altitudes are separated (Saussureaetum ovatae and Paraquilegietum anemonoidis). In this part, Rhinactinidietum popovii is distributed as a community at moderate elevations with a mean altitude of $2,500 \mathrm{~m}$, but with several plots in the subnival zone up to $3,600 \mathrm{~m}$ above sea level. The field observations and analyses of the literature indicate that typical petrophytic associations for the subnival zone are limited to Saussureaetum ovatae and Paraquilegietum anemonoidis, with their diagnostic species rarely descending below $3,000 \mathrm{~m}$. Rhinactinidia popovii was also reported from lower elevations, sometimes even below $1,400 \mathrm{~m}$ a.s.l. in the montane zone. Obviously, along with altitude, other environmental factors have to be considered. There is a quite apparent group of associations preferring northern exposition with lower insolation and a cooler bioclimate (e.g. Achoriphragmetum pinnatifidi, Inuletum glaucae). In the upper part of the DCA plot, the associations of Asperulo-Stipetum zeravshanicae are grouped. This community clearly prefers warmer places with southern expositions.

The $\mathrm{pH}$ of the rock substrate did not play a significant role in the distinction of the plant communities of the rock clefts and ledges in the alpine and subnival zones of Pamir-Alai. Almost all phytocoenoses are related to alkaline or strongly alkaline substrates, such as limestone, dolomite, or base rich shale and conglomerates.

\section{Conclusions}

During our recent surveys of petrophytic plant communities in Pamir Alai Mts we have been assured 
that this type of vegetation is extremely diverse thanks to immense altitudinal, bioclimatic, geological differences between mountain ranges and unusual rate of endemism of chasmophytic flora. However, our field observations have just started to yield sufficient knowledge about the petrophytic vegetation of the Pamir-Alai mountain system. The preliminary research and initial phytosociological documentation suggest several other associations of humid and shadow crevices with ferns, small fissures and crevices in the montane and colline zones and several other groups of epilithic phytocoenoses related to screes, taluses and rock terraces [23,39]. Thus, there is still a need to conduct further research of these habitats in Tajikistan as well as in all of Middle Asia. Keeping in mind both, the extreme richness and endemism of rock vegetation, and the serious threats to the Middle Asian hotspot of biodiversity [33,96], undoubtedly effective conservation measures should be implemented to protect this valuable part of Tajik's nature against global and regional anthropogenic changes like climate warming, mining or intensification of grazing. It would be also useful to determine endangerment

\section{References}

[1] Ovczinnikov P.N., Flora Tadzhikskoi SSR. 1, Paprotnikoobraznye - Zlaki, Izdatelstvo Akademii Nauk SSSR, Moskwa - Leningrad, 1957

[2] Ovczinnikov P.N., Flora Tadzhikskoi SSR. 2, Osokovye - Orkhidnye, Izdatelstvo Akademii Nauk SSSR, Moskwa - Leningrad, 1963

[3] Ovczinnikov P.N., Flora Tadzhikskoi SSR. 3, Opekhovye - Gvozdichnye, Izdatelstvo Nauka, Leningrad, 1968

[4] Ovczinnikov P.N., Flora Tadzhikskoi SSR. 5, Krestotsvetne - Bobovye, Izdatelstvo Nauka, Leningrad, 1978

[5] Ovczinnikov P.N., Koczkareva T.F., Flora Tadzhikskoi SSR. 4, Rogolistnikovye Rozotsvetnye, Izdatelstvo Nauka, Leningrad, 1975

[6] Ovczinnikov P.N., Kinzikaeva G.K., Flora Tadzhikskoi SSR. Vol. 6, Bobovye (rod Astragal) - Tsinomorievye, Izdatelstvo Nauka, Leningrad, 1981

[7] Chukavina A.P., Flora Tadzhikskoi SSR. 7. Zontichnye - Verbenovye, Izdatel'stvo Nauka, Leningrad, 1984

[8] Kochkareva T.F., Flora Tadzhikskoi SSR. 8. Kermekovye - Podorozhnikovye, Izdatelstvo Nauka, Leningrad, 1986 status of chasmophytic phytocoenoses as well as the plant species contributing to this type of vegetation. Despite that there is a capacity for petrophytic plants to compensate to some extent the increase of temperature and decline of humidity (e.g. shifting upwards or changing expositions [97]), considerable climatic changes could initiate the withdrawal of many plants and vegetation types. Therefore, a long-term research project studying chasmophytic vegetation is strongly recommended.

\section{Acknowledgements}

We are very grateful to G. Lazkov Ph.D. (vascular plants) and Vitezlslav Plašek Ph.D. (mossess) for their help in species determination. Special thanks to Prof. Adam Bodzioch for determination of rock samples. The authors also wish to thank F. Abdurahimova from the Nature Protection Team Dushanbe for assistance and help in organizing expeditions. The project was partially funded by the Polish Ministry of Science, grant No N304 $377838 / 2010$.
[9] Kinzikaeva G.K., Flora Tadzhikskoi SSR. 9. Marenovye - Slozhnotsvetnye, Izdatelstvo Nauka, Leningrad, 1988

[10] Rasulova M.R., Flora Tadzhikskoi SSR. 10, Slozhnotsvetnye, Izdatelstvo Nauka, Leningrad, 1991

[11] Zakirov K.Z., Flora i rastitelnost basseina reki Zeravshan. 2, konspekt flory, Izdatelstvo Akademia Nauk Uzbekskey SSR, Tashkent, 1961

[12] Tzvelev N.N., Zlaki SSSR, Izdatelstvo Nauka, Leningrad, 1976

[13] Ikonnikov S.S., Notulae ad floram Pamir and Badachschan, Novosti Sist. Vyss. Rast., 1983, 20, 187-195

[14] Lazkov G., Gastrolychnis alexeenkoi Lazkov (Caryophyllaceae) - a new species to the flora of Tajikistan, Novosti Sist. Vyss. Rast., 2008, 20, 68-69

[15] Nobis M., Nowak A., Zalewska-Gałosz J., Potamogeton pusillus agg. in Tajikistan (Middle Asia), Acta Soc. Bot. Pol., 2010, 79(3), 235-238

[16] Nobis M., Kowalczyk T., Nowak A., Eleusine indica (Poaceae): a new alien species in the flora of Tajikistan, Pol. Bot. J., 2011, 56(1), 121-123

[17] Nobis M., Remarks on the taxonomy and nomenclature of the Stipa tianschanica complex 
(Poaceae), on the base of a new record for the flora of Tajikistan (central Asia), Nord. J. Bot., 2011a, 29, 194-199

[18] Nobis M., Nowak A., New data on the vascular flora of the Central Pamir Alai Mountains Tajikistan, Central Asia), Pol. Bot. J., 2011a, 56(2), 195-201

[19] Nobis M., Nowak A., New data to the vascular flora of the central Pamir Alai Mountains (Tajikistan, Central Asia). Part II, Čas. Slez. Muz. Opava (A), 2011b, 60, 259-262

[20] Khassanov F.O., Shomuradov H., Tobaev K., A new Allium L. species from Middle Asia, Linz. Biol. Beitr., 2007, 39(2), 799-802

[21] Nobis M., Stipa xbrozhiana (Poaceae) nothosp. nov. from the western Pamir Alai Mts (middle Asia) and taxonomical notes on Stipaxtzvelevii, Nord. J. Bot., 2011b, 29, 458-464

[22] Nowak A., Nobis M., Tentative list of endemic vascular plants of Zeravshan Mts in Tajikistan (Middle Asia): distribution, habitat preferences and conservation status of species, Biodiv. Res. Conserv., 2010, 19, 65-80

[23] Nowak A., Nowak S., Nobis M., Distribution patterns, ecological characteristic and conservation status of endemic plants of Tadzhikistan - A global hotspot of diversity, J. Nat. Conservat., 2011, 19, 296-305

[24] Mittermeier R.A., Gil P.R., Hoffman M., Pilgrim J., Brooks T., Goettsch-Mittermeier C., et al. Hotspots revisited: Earth's biologically richest and most threatened terrestrial ecoregions, Conservation International, 2006

[25] Giam X., Bradshaw C.J.A., Tan H.T.W., Sodhi N.S., Future habitat loss and the conservation of plant biodiversity, Biol. Conserv., 2010, 143, 1594-1602

[26] Fay M., Patel H., A simple index of vulnerability to climate change, Background paper prepared for World Bank report, Washington, DC, 2008

[27] Baettig R., Michèle B., Wild M., Imboden D.M., A climate change index: Where climate change may be most prominent in the 21st century, Geophys. Res. Lett., 2007, 34, 457-469

[28] Favarger C., Endemism in the montane floras of Europe, pp. 191-204, [In:] Valentine D.H (ed.). Taxonomy, Phytogeography and Evolution. Academic Press, London and New York, 1972

[29] Agakhanjanz O., Breckle S.-W., Origin and evolution of the mountain flora in Middle Asia and neighbouring mountain regions, Ecol. Stud., 1995, 113, 21-67

[30] Agakhanjanz O., Breckle S.-W., Plant diversity and endemism in high mountains of Central Asia, the Caucasus and Siberia, [In:] Körner, Ch., Spehn, E.
(Eds), Mountain biodiversity - a global assessment. Parthenon Publ. Group, Boca Raton, New York, 2002

[31] Médail F., Verlaque R., Ecological characteristics and rarity of endemic plants from southeastern France and Corsica: implications for biodiversity conservation, Biol. Conserv., 1997, 80, 269-281

[32] Kazakis G., Ghosn D., Vogiatzakis I.N., Papanastasis V.P., Vascular plant diversity and climate change in the alpine zone of the Lefka Ori, Crete, Biodivers. Conserv., 2006, 16, 1603-1615

[33] Grabherr G., Gottfried M., Pauli H., Climate effects on mountain plants, Nature, 1994, 369, 448

[34] Dirnböck T., Dullinger S., Grabherr G., A regional impact assessment of climate and land-use change on alpine vegetation, J. Biogeogr., 2003, 30, 401-417

[35] Nowak A., Nobis M., Distribution patterns, floristic structure and habitat requirements of the alpine river plant community Stuckenietum amblyphyllae ass. nova (Potametea) in the Pamir Alai Mountains (Tajikistan), Acta Soc. Bot. Pol., 2012, 81(2), 101-108

[36] Nowak A., Nobis M., Distribution, floristic structure and habitat requirements of the riparian forest community Populetum talassicae ass. nova in the Central Pamir-Alai Mts (Tajikistan, Middle Asia), Acta Soc. Bot. Pol., 2013, 82(1), 47-55

[37] Nowak S., Nowak A., Nobis M., Weed communities of rice fields in the central Pamir Alai Mountains (Tajikistan, Middle Asia), Phytocoenologia, 2013, 43(1-2), 101-126

[38] Nowak S., Nowak A., Nobis M., Nobis A., Weed vegetation of cereal crops in Tajikistan (Pamir Alai Mts, Middle Asia), Phytocoenologia, 2013, 43(3-4), 225-243

[39] Nowak A., Nowak S., Nobis A., Nobis M., Vegetation of soild rock faces and fissures of the alpine and subnival zone in the Pamir Alai Mountains (Tajikistan, Middle Asia), Phytocoenologia, 2014, 44 , in print

[40] Meier H., Braun-Blanquet J., Classe des Asplenietales rupestres, groupements rupicoles, Prodr. Pflanzenges., 1934, 2, 1-47

[41] Mucina L., Asplenietea trichomanis, [In:] Grabherr G., Mucina L. (eds), Die Pflanzengesellschaften Österreichs. Teil II. Natürliche waldfreie Vegetation. Jena, Stuttgart, New York, 1993

[42] Valachovič M., Dierssen K., Dimopoulos P., Hadač E., Loidi J., Mucina L., et al., The vegetation of screes - A synopsis of higher syntaxa in Europe, Folia Geobot. Phytotax., 1997, 32, 173-192

[43] Kosiński M., Synecological differentiation of the scree vegetation of the Polish Tatra Mountains, Phytocoenologia, 2001, 31(4), 499-520 
[44] Pott R., The plant communities of Germany [Die Pflanzengesellschaften Deutschlands], 2 Aufl, Verlag Eugen Ulmer, Stuttgart, 1995

[45] Schubert R., Hilbig W., Klotz S., Determination key to the plant communities of Middle- and North-East Germany [Bestimmungsbuch der Pflanzengesellschaften Mittel- und Nordostdeutschlands], G. Fischer, Jena-Stuttgart, 1995

[46] Matuszkiewicz W., Guide to plant communities of Poland [Przewodnik do oznaczania zbiorowisk roślinnych Polski], Wydawnictwo Naukowe PWN, Warszawa, 2007

[47] Tzonev R.T., Dimitrov M.A., Roussakova V.H., Syntaxa according to the Braun-Blanquet approach in Bulgaria, Phytol. Balcan., 2009, 15(2), 209-233

[48] Sanda V., ÖllererK., Burescu P., The Phytocoenoses of Romania [Fitocenozele din România], Ars Docendi, Universitatea din Bucuresti, Bucuresti, 2008

[49] Chytrý M. (ed)., Vegetation of Czech republic 2: Ruderal, weed, rock and scree vegetation [Vegetace České republiky, 2: Ruderální, plevelová, skalní a sut'ová vegetace], Praha: Academia, 2009

[50] Mota Poveda J.F., Gómez Mercado F., Valle Tendero F., Rupicolous vegetation of the betic ranges (south Spain), Vegetatio, 1991, 94, 101-113

[51] Ortiz S., Rodriguez-Oubiňa J., Synopsis of the Rupicolous Vegetation of Galicia (North-western Iberian Peninsula), Folia Geobot. Phytotax., 1993, 28, 15-49

[52] Carmona E.C., Luque M.M., Tendero F.V., The plant communities of the Asplenietea trichomanis in the SW Iberian Peninsula, Folia Geobot. Phytotax., 1997, 32, 361-376

[53] Dimopoulos P., Sýkora K.V., Mucina L., Georgiadis T., The high-rank syntaxa of the rock-cliff and scree vegetation of the mainland Greece and Crete, Folia Geobot. Phytotax., 1997, 32, 313-334

[54] Deil U., The class Adiantetea in the Mediterranean area - a state of knowledge report, Ann. Bot., 1998, 56(1), 73-78

[55] Parolly G., Phytosociological studies on high mountain plant communities of the South Anatolian Taurus mountains. 1, Scree plant communities (Heldreichietea): A synopsis, Phytocoenologia, 1998, 28(2), 233-284

[56] Reyes-Betancort J.A., Wildpret de la Torre W., León Arencibia M.C., The vegetation of Lanzarotte (Canary Islands), Phytocoenologia, 2001, 31(2), 185-247
[57] Onipchenko V.G., Alpine vegetation of the Teberda Reserve, the Northwestern Caucasus. Veröffentlichungen des Geobotanischen Institutes der ETH Stiftung, Rubel. Zürich, 2002, 168

[58] Eren Ö., Gökçeoğlu M., Parolly G., The flora and vegetation of Bakirli Daği (Western Taurus Mts, Turkey), including annotations on critical taxa of the Taurus range, Willdenowia, 2004, 34, 463-503

[59] Ermolaeva O. Yu., The petrophyte plant communities of high mountain limestone area, the West Caucasus, Vegetation of Russia, 2007, 10, 23-37

[60] Deil U., Galán De Mera A., Orellana J.A., Rock and scree plant communities in the Serra de Monchique (SW Portugal), Feddes Repert., 2008, 119(5-6), 556-585

[61] Terzi M., D’Amico F.S., Chasmophytic vegetation of the class Asplenietea trichomanis in south-eastern Italy, Acta Bot. Croat., 2008, 67(2), 147-174

[62] Golub V.B., Grechushkina N.A., Sorokin A.N., Nikolaychuk L.F., Plant communities on rock outcrops in the northwest part of the Black See Caucasian Coast, Vegetation of Russia, 2009, 14, 3-14

[63] Bergmeier E., Dimopoulos P., Mucina L., Validation of some alliances of the Aegean chasmophytic vegetation of the Asplenietea trichomanis, Lazaroa, 2011, 32, 183-186

[64] Hein P., Kürschner H., Parolly G., Phytosociological studies on high mountain plant communities of the Taurus mountains (Turkey). 2. Rock communities, Phytocoenologia, 1998, 28(4), 465-563

[65] Quézel P., Contribution to the phytosociology of Taurus range [Contributions à l'étude phytosociologiques du massif du Taurus], Phytocoenologia, 1973, 1, 131-222

[66] Noroozi J., Akhani H., Willner W., Phytosociological and ecological study of the high alpine vegetation of Tuchal Mountains (Central Alborz, Iran), Phytocoenologia, 2010, 40(4), 293-321

[67] Ermakov N., Chytrý M., Valachovič M., Vegetation of the rock outcrops and screes in the foreststeppe and steppe belts of the Altai and Western Sayan Mts., southern Siberia, Phytocoenologia, 2006, 36(4), 509-545

[68] Kojima T., A geobotanical study of Ephedretum gerardianae in north central Nepal, Phytocoenologia, 1990, 19(1), 93-108

[69] Stanjukovich K. W., Vegetation [Rastitelnost], 358-435, [In:] C. M. Saidmuradow, K. W. Stanjukovich (eds.), Tajikistan. Nature and Natural resources [Tadzhikistan. Priroda i prirodnye resursy], Dushanbe: Izdatelstvo Donish, 1982 
[70] Dzhuraev A., Bio-ecological and fertilised forms of vegetation of screes and taluses of Hissar range [Bioloho-ecolohicheskie i zhizneynye formy rastitelnosti pervichnyh osypiey Hissarskoho hrebta], 1970, 13, 38-50

[71] Dzhuraev A., Rastitelnost pervichnyh osypiey zapoviednika „Ramit“. Doklady Akademii Nauk Tadzhikskoy SSR, 1972a, 15(12), 85-97

[72] Dzhuraev A., Scree vegetation of Takob valley (Hissar range) [Rastitelnost pervichnyh osypiey ushchelya Takob (Hissarskij hrebet)], Doklady Akademii Nauk Tadzhikskoy SSR, 1972b, 15(12), 44-46

[73] Vladimirova W.N., Climate zones [Tipy klimatov], 54-55, [In:] Narzikulov I.K., Stanjukovich K.W. (eds), Atlas Tajikskoi SSR, Akademia Nauk Tadzhikskoi SSR, Dushanbe-Moskva, 1968

[74] Latipova W.A., Precipitation [Kolichestvo osadkov], 68-69, [In:] Narzikulov I.K., Stanjukovich K.W. (eds), Atlas Tajikskoi SSR, Akademia Nauk Tajikskoi SSr, Dushanbe-Moskva, 1968

[75] Narzikulov I.K., Stanjukovich K.W., Atlas Tajikskoi SSR, Akademia Nauk Tajikskoi SSR, DushanbeMoskva, 1968

[76] Nedzvedskiy A.P., Geology [Geologicheskoe stroenye], 14-15, [In:] Narzikulov I.K., Stanjukovich K.W. (eds), Atlas Tajikskoi SSR, Akademia Nauk Tajikskoi SSr, Dushanbe-Moskva, 1968

[77] Braun-Blanquet J., Plant sociology, basics for vegetation science [Pflanzensoziologie, Grundzüge der Vegetationskunde], Springer, Wien, 1964

[78] Tichý L., JUICE, software for vegetation classification, J. Veget. Sci. 1, 2002, 13, 451-453

[79] Roleček J., Tichý L., Zelený D., Chytrý M., Modified TWINSPAN classification in which the hierarchy respects cluster heterogeneity, J. Veget. Sci. 1, 2009, 20, 596-602

[80] Ter Braak C.J.F., Šmilauer P., CANOCO Reference Manual and CanoDraw for Windows User's guide: Software for Canonical Community Ordination (version 4.5), Microcomputer Power, Ithaca, New York, USA, 2002

[81] Dierschke H., Plant sociology [Pflanzensoziologie], Ulmer, Stuttgart, 1994

[82] Weber H.E., Moravec J., Theurillat J.P., International code of Phytosociological Nomenclature. 3rd edition, J. Veget. Sci., 2000, 11, 739-768

[83] Willner W., The association concept revisited, Phytocoenologia, 2006, 36, 67-76

[84] Czerepanov S.K., Plantae Vasculares URSS, Nauka, Leningrad, 1995.
[85] Nobis M., Nowak A., Nobis A., Stipa zeravshanica sp. nov. (Poaceae) a new endemic species from rocky walls of the western Pamir Alai Mountains (Middle Asia), Nord. J. Bot., 2013, 31, 666-675

[86] Schischkin B.K., Bobrov E.G., Flora SSSR. Vol. XXIV, Izdatelsvo Akademii Nauk SSSR, MoskvaLeningrad, 1957

[87] Strid A., Phytogeographical aspects of the Greek mountain flora, Fragm. Flor. Geobot, 1993, Suppl., 2, 411-433

[88] Snogerup S., Evolutionary and plant geographical aspects on chasmophytic communities, pp. 157-170, [In:] P. H. Davis, P. Harper, I. E. Hedge (eds), Plant life of South West Asia, Edinburgh, 1971

[89] Deil U., Synvicariance and synphylogeny, evolution of plant communities [Synvikarianz und Symphylogenie], Zur Evolution von Pflanzengesellschaften, Ber. Reinh.-Tüxen-Ges., 1999, 11, 223-244

[90] Whittaker R.J., Fernandez-Palacios J.M., Island Biogeography: Ecology, Evolution, and Conservation. Oxford University Press, Oxford, 2007

[91] Noroozi J., Pauli H., Grabherr G., Breckle S.-W., The subnival-nival vascular plant species of Iran: a unique high-mountain flora and its threat from climate warming, Biodivers. Conserv., 2011, 20, 1319-1338

[92] Speziale K.L., Ezcurra C., The role of outcrops in the diversity of Patagonian vegetation: Relicts of glacial palaeofloras? Flora, 2012, 207, 141-149

[93] Deil U., Rock vegetation on both sides of Gibraltar's road [Felsgesellschaften beiderseits der Straße von Gibraltar], Hoppea, 1994, 55, 757-814

[94] Deil U., Hammoumi M., Contribution à l'étude des groupements rupicoles des Bokkoya (Littoral du Rif Central, Maroc), Acta Bot. Malacitana, 1997, 22, 131-146

[95] Galán De Mera A., Cortés J. E., Sánchez García I., The rocks vegetation of Gibraltar [La vegetación del Peñón de Gibraltar], Acta Bot. Malacitana, 2000, 25, 107-130

[96] Pauli H., Gottfried M., Reiter K., Grabherr G., Signals of range expansions and contractions of vascular plants in the high Alps: observations $(1994-2004)$ at the GLORIA master site Schrankogel, Tyrol, Austria, Glob. Change Biol., 2007, 13, 147-156

[97] Deil U., Distribution, ecology and phytosociology of the $\mathrm{N}$ Moroccan endemic Ptilostemon leptophyllus (Compositae), Willdenowia, 2006, 36, 413-422 